\title{
Treatment of First Ladies in American Government and Presidency Textbooks: Overlooked, yet Influential, Voices
}

\author{
Anthony J. Eksterowicz, James Madison University \\ Robert P. Watson, University of Hawaii, Hilo
}

Lady Bird: You want to listen for about one minute to my critique, or would you rather wait until tonight?

LBJ: Yes, ma'am. I'm willing now.

Lady Bird: I thought you looked strong, firm, and like a reliable guy. Your looks were splendid. The close-ups were much better than the distance ones.

LBJ: You can't get them to do it. Lady Bird: During the statement you were a little breathless and there was too much looking down and I think it was a little too fast. Not enough change of pacc. Dropping voice at the end of sentence. There was a considerable pickup in drama and interest when the questioning began. Your voice was noticeably better and your facial expressions noticeably better. (Beschloss 1997, 272-73)

$\mathrm{T}$ his exchange occurred between President Johnson and his wife following a press conference on Saturday, March 17, 1964. It is rather remarkable in what it reveals. The first lady was well aware of her husband's performance during the press conference and was well versed in

Anthony J. Eksterowicz is professor of political science and coeditor of The PostCold War Presidency (Rowman \& Littlefield, 1999) and Public Journalism and Political Knowledge (Rowman \& Littlefield, 2000).

Robert P. Watson is associate professor of political science and author of The Presidents' Wives: Reassessing the Office of the First Lady (2nd ed., Lynne Rienner, 2000) and author of the reference work, First Ladies of the United States (Lynne Rienner, 2000). the intricacies of public speaking and the importance of public image. More than that, she was obviously ready to give advice and criticism. The transcript illustrates powerfully the truth of the argument that first ladies are the most important advisers to presidents (Anthony 1990, 1991; Caroli 1987; Mayo 1993; Watson 1997, 1999). While each first lady has interpreted and carried out her duties differently, there is ample evidence that modern first ladies have actively championed social and charitable projects and involved themselves in the executive decisionmaking and policy-setting processes (Anthony 1990, 1991; Caroli 1987; Gutin 1989; Watson 1999).

First Lady Nancy Reagan became involved in the fight against drug abuse, but she was also intimately involved in the Iran-Contra machinations. Her repeated clashes with her husband's chief of staff, Donald Regan, eventually led to Regan's resignation (Anthony 1991, 394-96; Jones 1994). In reverse fashion, Hillary Clinton is widely remembered as the point-person in the fight for health care reform in 1993-94 but gets much less credit for her charitable work on behalf of children (Quirk and Hinchliffe 1996, 274-75).

Still, Mrs. Clinton's political participation simply places her in a long line of politically active first ladies stretching all the way back to Martha Washington. First ladies have been extremely influential in the policy process, or at least much more influential than a review of both modern major presidential textbooks and general education American government textbooks indicates.

The coverage of first ladies in college textbooks is sporadic, spotty, and sometimes nonexistent. Authors give little, if any, consideration to how first ladies have shaped the White House, the presidency, their husbands' careers, and the nation. In other words, textbooks generally mute first ladies' voices. As one group of scholars noted, "The failure of political scientists and historians to consider the political role of first ladies neglects the role of a key player in the president's inner circle" (O'Connor, Nye, and Van Assendelft 1997, 835). This snubbing of first ladies is regrettable, especially since the average general education government course enrolls more females than males (see Mann 1996). Coverage of first ladies' power and influence could provide female students with positive female role models in the arena of national politics. While there have been notable recent efforts to correct the traditional lack of consideration of women in textbooks and university curricula, this reformist movement appears to have bypassed the field of presidency research.

In this article we will highlight the increasing importance of first ladies in the policy process and of the first ladyship as an institution within the Executive Office of the President. Second, we will discuss a content analysis of 10 major American government and 10 major presidency textbooks that revealed the coverage of first ladies to be minimal and lacking any historical or analytical consistency across texts. Third, we suggest a few remedies to this situation. We believe that it is important for all students enrolled in introductory American government courses to understand how first ladies can influence presidential decision making and the policy process. Most of the students enrolled in introductory courses will not go on to major in history or political science, so teach- 


\section{TABLE 1}

\section{American Government Textbooks Analyzed}

Burns, James MacGregor, J.W. Peltason, Thomas E. Cronin, and David B. Magleby. 1998. Government by the People. 17th ed., natl. ver. Upper Saddle River, NJ: Prentice-Hall.

Fiorina, Morris P., and Paul E. Petersen. 1999. The New American Democracy. Alt. ed. Boston: Allyn \& Bacon.

Gitelson, Alan R., Robert L. Dudley, and Melvin J. Dubnik. 1998. American Government. 5th ed. Boston: Houghton Mifflin.

Greenberg, Edward S., and Benjamin I. Page. 1999. The Struggle For Democracy. 2nd ed., brief ver. New York: Longman.

Janda, Kenneth, Jeffrey M. Berry, and Jerry Goldman. 1999. The Challenge of Democracy: Government in America. 6th ed. Boston: Houghton Mifflin.

Lowi, Theodore J., and Benjamin Ginsberg. 1998. American Government: Freedom and Power. 5th ed. New York: W.W. Norton.

Miroff, Bruce, Raymond Seidelman, and Todd Swanstrom. 1998. The Democratic Debate. 2nd ed. Boston: Houghton Mifflin.

Mladenka, Kenneth R. 1997. The Unfinished Republic: American Government in the Twenty-First Century. Upper Saddle River, NJ: Prentice-Hall.

O'Connor, Karen, and Larry J. Sabato. 1999. American Government: Continuity and Change. Boston: Allyn \& Bacon.

Wilson, James Q., and John J. Dilulio. 1998. American Government: Institutions and Policies. 7th ed. Boston: Houghton Mifflin.

ers may get only one chance to inform them about the influence, contributions, and lives of first ladies.

\section{The Increasing Importance of First Ladies}

The first ladyship dates, of course, to the founding of the nation. As Martha Washington traveled from her home in Virginia to join her husband in the temporary capital city of New York, she worried about what would be expected of her and what duties she would be required to perform as the president's spouse. ${ }^{1}$ The Constitution was altogether silent on the matter and, as a result, Martha Washington literally forged the office through her actions. In particular, Martha appears to have fashioned three enduring "roles" associated with the office: public figure, social hostess, and presidential confidante. Although the first ladyship has been expanded over the last two centuries as the office's occupant's temperament has allowed and circumstances have demanded, the roles and duties per- formed by Martha Washington have consistently permitted first ladies to exercise influence in and beyond the White House.

For example, during her trip to join her husband for his inauguration (and even earlier), Mrs. Washington found herself greeted by cheering crowds of admirers, military escorts, and roaring cannonade salutes. She appears to have been quite possibly the most admired and well-known woman of her time. "Lady Washington" emerged as a symbol of the new nation and a visible part of her husband's presidency (Fields 1994). Her popularity increased when the president entrusted her to preside over the full social calendar of presidential dinners and receptions. Martha Washington also served as her husband's confidante. The "Father of His Country" found moral support and a source of strength in his wife (Brookhiser 1996). Whether by visiting George in camp during the most trying times of the Revolutionary War, caring for her husband during his two serious illnesses while in of- fice, or presiding over their bustling plantation home and business and later the presidential residence, Martha Washington served, in the words of her obituary, as Washington's "worthy partner" (Bourne 1982; Fields 1994).

Mrs. Washington's three immediate successors as first lady-Abigail Adams, Dolley Madison (Jefferson's wife, Martha, died in 1782; her oldest daughter, Patsy, and Mrs. Madison filled in), and Elizabeth Monroe-each institutionalized the roles she had pioneered by embodying them. Mrs. Adams was her husband's most trusted confidante and political advisor throughout his long public life. She regularly sent him updates on the political scene back home while he was overseas or away from Boston and often advised him on political issues during his presidency (Akers 1980; Gelles 1992). Dolley Madison played the role of social hostess to its fullest, becoming, arguably, the greatest hostess ever to preside over the White House. During her service to Jefferson and her husband, Mrs. Madison frequently blended social affairs with the craft of politics by timing events, arranging seating, and personally charming guests so as to advance the president's policies and political standing (Arnett 1972; Moore 1979). The next presidential spouse, Elizabeth Monroe, was, like her predecessors, a well-known public figure who enjoyed public adulation at home and abroad. To her many admirers in France, Mrs. Monroe was known as "la belle Americaine" (Wootton 1987).

Over time, first ladies came to fill two more "traditional" roles: keeper of the White House and co-campaigner. When the White House and its furnishings have required renovation and updating, the responsibilities for overseeing the work and making the necessary purchases has fallen to first ladies, as have responsibilities for preservation and decoration (Aikman 1991). Several first ladies, including Caroline Harrison, Edith Roosevelt, and Jacqueline Kennedy, have presided over historic renovations of the building and the preservation of its furnishings, and most first ladies have been responsi- 
ble for everything from White House menus and entertainment to interior design and china patterns. At the end of the nineteenth century, the advent of the "front porch" campaign effectively made the first lady a co-campaigner for the presidency. Frances Cleveland and Ida McKinley appeared as often as their husbands on campaign paraphernalia and literature and spent nearly as much time greeting hosts of curious well wishers and voters. The first lady's campaign responsibilities have grown with each election.

The twentieth century brought an expansion in the scope of activities of first ladies, in part due to the changing roles of women in society. The first lady first acquired a staff in 1902, when Isabella Hagner James was transferred from her position as a clerk in the War Department to assist Edith Roosevelt with the mail she received. The Office of the First Lady has since grown to rival in staff, office space, and resources those of the most senior presidential advisors. From a high of roughly 40 employees under Jackie Kennedy, the Office of the First Lady now consists of just over 20 staffers (Rosebush 1987).

The addition of staff and resources has further contributed to the institutionalization of the first ladyship and it has allowed first ladies to extend their influence and activism. First ladies now regularly champion important social causes, make numerous public appearances, travel extensively at home and abroad, and campaign for both their husbands' presidential policy initiatives and candidates from their political party. The first lady has emerged as an influential political actor and an active participant in the policy process. First ladies like Hillary Clinton now head presidential task forces. Rosalynn Carter presided over mental health reform during her husband's administration and Eleanor Roosevelt briefly served as assistant head of the Office of Civil Defense. In less official capacities, many first ladies have lobbied Congress. Eleanor Roosevelt, Rosalynn Carter, and Hillary Clinton join "second ladies" Joan Mondale, Marilyn Quayle, and Tipper Gore in

\section{TABLE 2}

\section{Presidency Textbooks Analyzed}

Cronin, Thomas E., and Michael A. Genovese. 1998. The Paradoxes of the American Presidency. New York: Oxford University Press.

DiClerico, Robert E. 1995. The American President. 5th. ed. Englewood Cliffs, NJ: Prentice-Hall.

Edwards, George C., and Stephen J. Wayne. 1994. Presidential Leadership: Politics and Policy Making. 3rd ed. New York: St. Martin's Press.

Hart, John. 1995. The Presidential Branch: From Washington to Clinton. 2nd ed. Chatham, NJ: Chatham House Publishers.

Jones, Charles O. 1994. The Presidency in a Separated System. Washington, DC: Brookings Institution.

McDonald, Forest. 1994. The American Presidency: An Intellectual History. Lawrence: University Press of Kansas.

Pfiffner, James. P. 1994. The Modern Presidency. New York: St. Martin's Press.

Thomas, Norman C., and Joseph A. Pika. 1997. The Politics of the Presidency. Washington, DC: CQ Press.

Warshaw, Shirley Ann. 1997. The Domestic Presidency: Policy Making in the White House. Boston: Allyn \& Bacon.

Wayne, Stephen J. 1996. The Road to the White House 1996. New York: St. Martin's Press.

having testified before Congress as experts on policy issues. Earlier in the past century, Ellen Wilson was successful in pushing legislation directed at improving the housing conditions of DC's poor and Florence Harding and Helen Taft helped manage their husbands' presidential campaigns.

Even though first ladies have wielded influence since Martha Washington first traveled to the new capital city, the first lady's activities and influence have become more overtly public and political in nature over the twentieth century. First ladies wield influence in private as behind-the-scenes advisors and in public as hostesses, advocates of charitable projects, and as political operatives. First ladies function as presidential partners and it would appear that they will continue to wield considerable influence into the new century.

\section{Methodology}

We examined two types of textbooks: general education American government textbooks and upper- division textbooks on the presidency. We selected textbooks we knew to be best sellers and required reading in courses at universities across the nation. All of the texts were published by major publishing firms between 1994 and 1999. The American government textbooks we analyzed are listed in Table 1. The presidential texts are in Table 2.

To fully gauge coverage of first ladies, we subjected each text to manifest content analysis and latent content analysis (Babbie 1983, 279). For manifest content analysis, we counted references to specific first ladies within the text and references to first ladies in general in subheadings, pictures, cartoons, and captions. We also counted the number of paragraphs and pages devoted to first ladies. Our calculations appear in Tables $3 \mathrm{~A}$ and $3 \mathrm{~B}$. Average scores were calculated for the manifest analyses. This methodology is similar to that employed by Eksterowicz and Cline (1991, 211-15).

For our latent content analysis, we measured the quality and depth of the textbooks' treatment of the first ladies and categorized each book as 


\section{TABLE 3A}

\section{References to First Ladies in American Government Texts}

\begin{tabular}{|c|c|c|c|c|}
\hline Text & References & Paragraphs & Pages & Other \\
\hline Burns et.al. & 17 & 10 & 1.3 & \\
\hline Fiorina and Petersen & 13 & 6 & 1.5 & \\
\hline Gitelsen et. al. & 1 & 1 & 0.3 & a \\
\hline Greenberg and Page & 1 & 1 & 0.25 & \\
\hline Janda et. al. & 18 & 11 & 2.8 & $b$ \\
\hline Lowi and Ginsburg & 20 & 13 & 2.5 & \\
\hline Miroff et. al. & 5 & 5 & 1.25 & \\
\hline Mladenka & 68 & 34 & 7.5 & \\
\hline O'Connor and Sabato & 27 & 18 & 3.2 & \\
\hline Wilson and Dilulio & 7 & 6 & 0.3 & \\
\hline TOTALS & 177 & 105 & 20.9 & \\
\hline AVERAGES & 17.7 & 10.5 & 2.09 & \\
\hline
\end{tabular}

giving first ladies minimum, moderate, or maximum coverage. To be included within the maximum category, a text would have had to analytically and systematicly examine the various roles performed by the first ladies and illustrate performance of these roles with historical examples. It would also have had to include consideration of the resources available to first ladies as well as the growth of her office.

Books with moderate treatment of first ladies contain mainly historical analysis of more than one first lady and their impact upon various public policies in more than a single section of the text. In texts with minimum coverage, first ladies were mentioned, seemingly as an afterthought, in, for example, chapters on civil rights, the media, or the presidency, but there was no sustained discussion of either their role or their office. The results of our latent content analyses appear in Tables $4 \mathrm{~A}$ and $4 \mathrm{~B}$.

In the American government texts, we examined chapters on democracy, the Constitution, civil rights, equality, economic policy, domestic policy, foreign policy, vot- ing and elections, political parties, media, campaigning, the presidency, and Congress. This represents well over half the total contents of these texts. In the presidency texts, we searched their indexes for any reference to first ladies. We then read the noted passages and made our calculations. We also looked for photographs and other mentions of first ladies in both types of textbooks.

All of the texts we examined are leading books in their field. We have no quarrel with their coverage of American politics and institutions or their contents in general beyond their omission of consideration of the first ladies. The quality of the treatment of other topics in many of these texts is truly outstanding. This points again to the extent of neglect of the first ladies throughout the discipline.

\section{Analysis}

Manifest content analysis of the selected American government texts indicates uneven treatment of first ladies. Four of the texts (Gitelsen, et al., Greenberg and Page, Miroff et al., and Wilson and Dilulio) barely mention first ladies. In fact, approximately one-third of the total refer-

\section{TABLE 3B}

\section{References to First Ladies in Presidency Texts}

\begin{tabular}{lcccc}
\hline \multicolumn{1}{c}{ Text } & Citations & Paragraphs & Pages & Other \\
\hline Cronin and Genovese & 31 & 22 & 2.75 & \\
DiClerico & 2 & 2 & 0.5 & 2 \\
Edwards and Wayne & 22 & 10 & 0.25 & \\
Hart & 1 & 1 & 0.5 & a \\
Jones & 4 & 3 & 0 & b \\
McDonald & 0 & 0 & 1 & \\
Pfiffner & 2 & 3 & 1.5 & \\
Thomas and Pika & 8 & 8 & 0.5 & \\
Warshaw & 6 & 6 & 11 & \\
Wayne & 4 & 58 & 1.1 & \\
TOTALS & 80 & 5.8 &
\end{tabular}

Notes: ${ }^{a}$ Five footnotes cite or mention first ladies.

${ }^{b}$ Hillary Clinton appears in the book's cover photo with Bill Clinton and Al Gore. 
TABLE 4A

Coverage of First Ladies in American Government Textbooks

\begin{tabular}{|c|c|c|c|}
\hline \multirow[b]{2}{*}{ Text } & \multicolumn{3}{|c|}{ Categories/Levels of Treatment } \\
\hline & Minimum & Moderate & Maximum \\
\hline Burns et. al & & $x$ & \\
\hline Fiorina and Petersen & & $x$ & \\
\hline Gitelson et. al. & $x$ & & \\
\hline Greenberg and Page & $x$ & & \\
\hline Janda et. al. & & $x$ & \\
\hline Lowi and Ginsburg & & $x$ & \\
\hline Miroff et. al. & $X$ & & \\
\hline Mladenka & & $x>>>$ & \\
\hline O'Connor and Sabato & & $x$ & \\
\hline Wilson and Dilulio & $x$ & & \\
\hline
\end{tabular}

ences, paragraphs, and pages for the entire group of ten textbooks are directly attributable to just one text (Mladenka). On average, the books devote only 2.09 pages to first ladies. Removing the Mladenka text, the averages drop to 12.1 references, 7.89 paragraphs, and a lowly 1.48 pages per book devoted to the first ladies. Obviously, the coverage of first ladies in American government texts is inadequate.

One might believe first ladies would receive more coverage in upper-division textbooks on the presidency than they do in more general American government textbooks. Our analysis does not support this conclusion. In fact, our manifest content analysis revealed that the presidency texts actually devote fewer pages, on average, to the discussion of first ladies than do government texts (see table 3B). Just as was the case with the American government texts, the level of treatment of first ladies was far from uniform in presidency texts. Among the latter group, two (Cronin and Genovese and Edwards and Wayne) account for the majority of all the references, paragraphs, and pages we counted. Excluding the Cronin and Genovese text significantly lowers the already low average of pages per presidency text devoted to first ladies. separate sections on first ladies. Although Hillary Clinton continued to lead all others in mentions, the "moderate" texts tend to take a historical approach to discussing the first ladyship and to list the accomplishments of various first ladies. None of these texts could be characterized in the maximum coverage category.

The Mladenka text deserves special mention. It contains a full seven-and-a-half pages of historical analysis of the actions of many first ladies and their respective abilities to influence decisions. We have indicated with arrows that this text comes very close to providing maximum coverage of first ladies. Indeed, it could serve as a model for others.

\section{Conclusions and Recommendations}

What type of picture can students of American government and the presidency glean from the treatment of first ladies in textbooks? The answers run from "none" to "incomplete." Many of these texts portray the first lady as simply an appendage of the president. Her political agenda, duties, and influence are ignored. But first ladies often have agendas of their own. Rosalynn

\section{TABLE 4B}

\section{Coverage of First Ladies in Presidency Textbooks}

\begin{tabular}{|c|c|c|c|}
\hline \multirow[b]{2}{*}{ Text } & \multicolumn{3}{|c|}{ Categories/Levels of Treatment } \\
\hline & Minimum & Moderate & Maximum \\
\hline Cronin and Genovese & & $x$ & \\
\hline Diclerico & $x$ & & \\
\hline Edwards and Wayne & & $x$ & \\
\hline Hart & $x$ & & \\
\hline Jones & $x$ & & \\
\hline McDonald & $x$ & & \\
\hline Thomas and Pika & $x$ & & \\
\hline Pfiffner & $x$ & & \\
\hline Warshaw & $x$ & & \\
\hline Wayne & $x$ & & \\
\hline
\end{tabular}


Carter was dedicated to providing mental health services. Lady Bird Johnson worked tirelessly to protect the environment and to "beautify" public spaces. Eleanor Roosevelt's extensive and ambitious agenda for her first ladyship was too broad to summarize in a sentence. While a few texts do offer glimpses of first ladies' efforts on behalf of social causes, none gives students enough information to understand why or how they were able to accomplish what they did. Moreover, a listing of first ladies' "pet projects" fails to capture the essence and range of activism and influence of the first ladyship.

Studying the increase in the budgets and staffing of the first lady's office is important because doing so will give students an understanding that the first lady can be a powerful force in executive politics. Similarly, study of the first lady's image and public opinion concerning the office, the legal parameters governing a first lady's activism in politics and policy, and the effect of a first lady's popular activities on presidential approval and the president's image can help students more fully understand the presidency. Textbooks on American government should, at a minimum, introduce students to the first lady by portraying the presidential spouse as a White House institution and a key player in presidential politics. The books should also provide a short history of the office, ideally in the section or chapter of the book devoted to the discussion of presidential aides and advisors or offices. Textbooks on the presidency should contain a separate chapter devoted to the first lady.

We urge authors of future American government and presidency texts to devote, at the least, a section of a chapter to the office of the first lady. This section should document how the first lady's office has developed, note the resources at her disposal, and include illustrative examples of how first ladies have used the resources at their disposal to influence politics and policies. While the first lady's office is not a constitutional one, and its occupant is unpaid and unelected, it is an important one.

What can instructors do until textbook authors begin writing about first ladies? Minimally, they can assign students supplementary reading from the articles ${ }^{2}$ and books on first ladies. They can also direct students to web sites like those maintained by the Office of the First Lady (www.whitehouse.gov/WH/EOP/ First_Lady/html/HILLARY_Home. html) and the National First Ladies' Library (www.firstladies.org). More enterprising instructors could encourage students to do interdisciplinary research projects involving first ladies. These projects can be individual or group activities, and could even involve students in other classes like history, sociology, public administration, and women studies. Such undergraduate research and sharing can go a long way toward filling the current textbook void.

First ladies have been important actors in the White House, within our political system, and in the policy process. If instructors and textbook writers fail to treat these actors in assessments of the American political system or the institution of the American presidency they will be doing a great disservice not only to first ladies but to their students.

\section{Notes}

1. A log of Martha's journey to New York City was kept by her traveling companion and George's relative, Lawrence Washington. The log reveals Martha's courage and uncertainty about the trip and the prospects of the presidency. The document is among the holdings at the Mount Vernon Historical Association Library, Mount Vernon, Virginia. See also, Joseph Fields' 1994 collection of Martha Washington's paper and letters, which includes a discussion of Martha's significance and letters on the subject.
2. A few scholarly journals have published articles on the first ladies. Additionally, in 1990, Presidential Studies Quarterly (20[3]) devoted one half of an issue to modern first ladies, and this year, The Social Science Journal (37[4]) ran a series on first lady scholarship.

\section{References}

Aikman, Lonnelle. 1991. The Living White House. Washington, DC: White House Historical Association.

Akers, Charles W. 1980. Abigail Adams. Boston: Little, Brown.

Anthony, Carl Sferrazza. 1990. First Ladies: The Saga of the Presidents' Wives and Their Power, 1789-1961. New York: Quill/William Morrow.

- 1991. First Ladies: The Saga of the Presidents' Wives and Their Power. Vol. 2. New York: William Morrow.

Arnett, Ethel Stephens. 1972. Mrs. James Madison: The Incomparable Dolley. Greensboro, NC: Piedmont Press.

Babbie, Earl. 1983. The Practice of Social Research. Belmont, CA: Wadsworth.

Beschloss, Michael R. 1997. Taking Charge: The Johnson White House Tapes, 1963 1964. New York: Simon and Schuster.
Bourne, Miriam Anne. 1982. First Family: George Washington and His Intimate Relations. New York: W.W. Norton.

Brookhiser, Richard. 1996. Founding Father: Rediscovering George Washington. New York: Free Press.

Caroli, Betty Boyd. 1987. The First Ladies. New York: Oxford University Press.

Eksterowicz, Anthony J., and Paul C. Cline. 1991. "Ratification of the Constitution: The Great Debate as Portrayed in American Government Textbooks." PS: Political Science and Politics 24 (June): 211-15.

Fields. Joseph E. 1994. "Worthy Partner": The Papers of Martha Washington. Westport, CT: Greenwood Press.

Gelles, Edith B. 1992. Portia: The World of Abigail Adams. Bloomington: Indiana University Press.

Gutin, Myra. 1989. The President's Partner:
The First Lady in the Twentieth Century. Westport, CT: Greenwood Press.

Jones, Charles O. 1994. The Presidency in a Separated System. Washington, DC: Brookings Institution.

Mann, Sheilah. 1996. "Political Science Departments Report Declines in Enrollments and Majors in Recent Years." PS: Political Science and Politics 29(September): $527-$ 33.

Mayo, Edith. 1993. "The Influence and Power of First Ladies." The Chronicle of Higher Education, September 15, A52.

Moore, Virginia. 1979. The Madisons: A Biography. New York: McGraw-Hill.

O'Connor, Karen, Bernadete Nye, and Laura Van Assendelft. 1997. "Wives in the White House: The Political Influence of First Ladies." Presidential Studies Quarterly 26: 835-53. 
Quirk, Paul J., and Joseph Hinchliffe. 1996. "Domestic Policy: The Trials of a Centrist Democrat." In The Clinton Presidency: First Appraisals, ed. Colin Campbell and Bert Rockman. New Jersey: Chatham House.
Rosebush, James S. 1987. First Lady, Public Wife. New York: Madison Books.

Watson, Robert P. 1997. "The First Lady Reconsidered: Presidential Partner and Political Institution." Presidential Studies Quarterly 27:805-17.
- 1999. The Presidents' Wives: Reassessing the Office of the First Lady. Boulder: Lynne Rienner.

Wootton, James E. 1987. Elizabeth Kortright Monroe. Charlottesville, VA: Ash LawnHighland.

\section{Appendix A \\ Scholarly Books on the First Ladies}

Anthony, Carl Sferrazza. 1990. First Ladies: The Saga of the Presidents' Wives and Their Power, 1798-1961. New York: Quill/William Morrow.

-. 1991. First Ladies: The Saga of the Presidents' Wives and Their Power. Vol. 2. New York: Quill/William Morrow.

Caroli, Betty Boyd. 1995. The First Ladies. New York: Oxford University Press.
Gutin, Myra. 1989. The President's Partner: The First Lady in the Twentieth Century. Westport, CT: Greenwood Press.

Gould, Lewis L., ed. 1996. American First Ladies: Their Lives and Their Legacy. New York: Garland.

Troy, Gil. 1997. Affairs of State: The Rise and Rejection of the Presidential Couple Since World War II. New York: Free Press.
Watson, Robert P. 1999. The Presidents' Wives: Reassessing the Office of First Lady. Boulder: Lynne Rienner.

—. 2000. First Ladies of the United States. Boulder: Lynne Rienner. 


\section{Future Teacher Features}

Sheilah Mann, Editor, "The Teacher"

Beginning soon, "The Teacher" will publish brief columns and practical essays on exemplary initiatives and programs in undergraduate and graduate education that can be useful models for other political science faculty and departments. Please review the topics proposed for these features and contact me (smann@apsanet.org) with your comments, suggestions for other topics, and offers to write a guest column or an essay.

\section{Columns}

- "Web Finds and Favorites": Contributors will prepare one-page reviews of web sites where faculty can find references, instructional exercises, or analytical methods and tools. We hope this will become a regular feature.

- "Conference Contributions": Contributors will provide one- or two-page reports on conference presentations and papers devoted to teaching resources, strategies, and/or evaluations, along with web and email addresses interested readers can use to read or request from the authors the original works.

\section{Practices and Perspectives Essays}

- "The Job Talk: What Departments Want to Hear from Job Candidates"

- Perspectives from different graduate and undergraduate political science departments

- "The (Departmental) Undergraduate Education Mission Statement"

- Perspectives from graduate and undergraduate institutions, both public and private

- "The 'Teaching Seminar' for Ph.D. Students"

- Objectives and core topics from several Ph.D. departmental seminars to prepare graduate students to teach undergraduates

- "The Teaching Philosophy Statement"

- Highlights from essays faculty contribute to their teaching portfolios or annual review folders.

- "How Teaching is Evaluated for Tenure and Promotion Decisions"

- "The Dissertation Proposal: Objectives and Expectations of Ph.D. Departments"

- "Collaborative Work in Undergraduate Education: Faculty Cooperation on Course or Curricular Design"

- "The Core Course or Course Sequence"

- Perspectives from graduate and undergraduate departments

- "Professional Development for High School Teachers: Courses, Workshops, Summer Institutes"

Articles along similar lines than those topics listed above would be of interest as well. 